\title{
Seismic Performance of RC Frame Buildings Resting on Sloping Ground
}

\author{
Kiran. $T^{1}$, N Jayaramappa ${ }^{2}$, \\ Associate professor, and Ishrat Fatima ${ }^{3}$, M.E student, Earthquake Engineering, Civil Engineering \\ Department, UVCE, Bangalore University, JnanaBharathi Campus, Bangalore 560056
}

\begin{abstract}
The structures are generally constructed on level ground; however, due to scarcity of level grounds the construction activities have been started on sloping grounds. There are two types of configuration of building on sloping ground, the one is step back and the other is step back setback. In this study, G+ 12 storeys $R C C$ building and the ground slope for $20^{\circ}, 30^{\circ} \& 40^{\circ}$ have been considered for the analysis. A comparison has been made with the building resting on level ground (setback). The modeling and analysis of the building has been done by using structure analysis tool ETAB, to study the effect of varying height of the column in bottom storey at different position during the earthquake. The results have been compared with the results of the building with and without level ground. The seismic analysis was done by linear static analysis and the response spectrum analyses have been carried out as per IS: 1893 (part 1): 2002. The results were obtained in the form of top storey displacement, drift, base shear and time period. It is observed that short column is affected more during the earthquake. The analyses showed that for construction of the building on sloppy ground the stepback setback building configuration is suitable.
\end{abstract}

Keywords: Sloping ground, Linear static analysis, Stepback, Stepback setback and Response spectrum analysis.

\section{Introduction}

Generally the structures are constructed on level ground. In some areas the ground itself is a slope. In that condition it is very difficult to excavation, leveling and it is very expensive .Due to the scarcity of level ground engineers started construction on sloppy ground itself. Some of the hilly areas are more prone to the earthquake. In that areas generally construction works carried out by locally available materials such as bamboo, timber, brick, RCC and also they gave more important to the light weight materials for the construction of houses. As the population density increases at hilly region requirement of structure also increases. The popularity and demand of multistory building on hilly slope is also increases.

Earthquakes are one of the most dangerous natural hazards. Earthquake occurs due to sudden movement of the tectonic plates as a results it release large amount of energy in a few seconds. The impact of this function is most harmful because it affects large vicinity, and which occurs sudden and unpredictable. It causes large scale loss of life and property and damages important services such as, sewerage systems, communication, power, transport and water supply etc. They not only destroy towns, cities and villages, but the result leads to weaken the financially viable and social structure of the country. To defeat from the problem we need to find out the seismic performance and lateral stability of the building structure.

In sloping ground the height of the column is different at the bottom storey. It is asymmetric in plane and elevation. The short columns are most effects and damage occurs during the earthquake. Care should be taken for making this building earthquake resistance. The various methods are used for the analysis such as static and dynamic. Due to the asymmetry dynamic analysis must be used for seismic analysis of the building. These methods are time history and response spectrum method. In the response spectrum method the data such as zone factor, type of soil etc. are applied from I.S.-1893. In time history method the actual record of accelelogram is applied on the building and analysis of the building is carried out in software. Time history method gives more realistic result compared to the response spectrum method because in time history the actual acceleration data of earthquakes are applied and response of building is studied. 1.1 Objectives

- To determine the ground slope varying from $0^{\circ}$ to $40^{\circ}$.

- To capture the response for the three types of modeling .

* Step back

* Set back (Level Ground)

* Step back set back

- To obtain capacity curve. 


\subsection{Methodology}

1.3 The methodology followed out to achieve the above mentioned objectives is as follows:

1. Setting up of properties required for analysis of hill buildings, like material properties, geometric properties, loading cases, etc.

2. Modelling of selected building configuration on sloping ground located in seismic zones IV using ETAB software.

3. Static and dynamic analysis of sloping ground structure as per IS 1893 (part 1)2002.

\section{Modeling And Analysis}

In the present study, three building configurations are considered, which include step back buildings, stepback setback buildings and set back buildings situated on sloping ground. Number of storey considered for each type of configurations is 12 storeys. Plan layout of each configuration includes 4 bays across the slope direction and 6 bays are considered along slope direction, which is kept same for all configurations of building frame. Slopes of ground considered are 20 degree, 30 degree and 40 degree with the horizontal. The columns are taken to be square to avoid the issues like orientation. The depth of footing below ground level is taken as $1.5 \mathrm{~m}$ where, the hard stratum is available.

\subsection{Geometric Properties And Material Properties are Given Below.}

Floor height: $3.5 \mathrm{~m}$

Spacing in X direction: $7.0 \mathrm{~m}$

Spacing in Y direction: $4.5 \mathrm{~m}$

Beam Sizes: 230 X $450 \mathrm{~mm}$

Column sizes : 550 X $550 \mathrm{~mm}$

Slab Thickness : $125 \mathrm{~mm}$

Live load : $3 \mathrm{kN} \backslash \mathrm{m} 2$

For Terrace : $1.5 \mathrm{kN} \backslash \mathrm{m} 2$

Floor finish : $1 \mathrm{kN} \backslash \mathrm{m} 2$

Concrete Grade : M25

Modulus of Elasticity : $25000000 \mathrm{kN} \backslash \mathrm{m} 2$

Poison's ratio : 0.2

Compressive strength : $25000 \mathrm{kN} \backslash \mathrm{m} 2$

Steel : Fe415, Strength of steel : $415000 \mathrm{kN} \backslash \mathrm{m} 2$

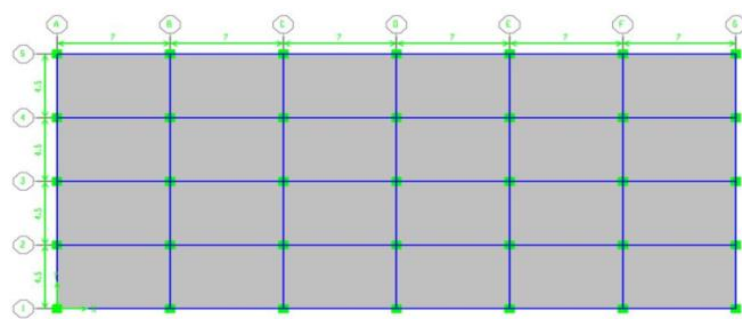

Fig 4.0: Typical plan layout of 6 X 4 bays

As per IS 1893 (part 1): 2002 following methods have been recommended to determine the design lateral loads which are:

1. Equivalent Static Method

2. Response Spectrum Method

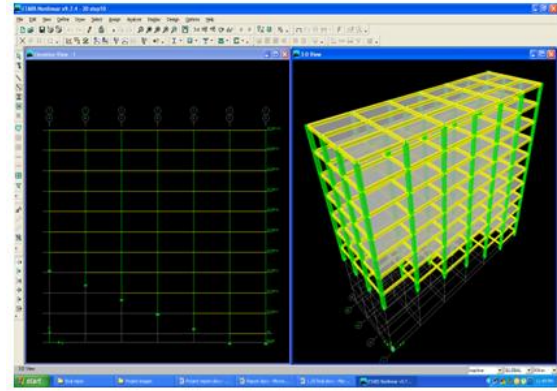

Fig 1.0: Typical 2D and 3D Step back building model on $20^{\circ}$ slope 


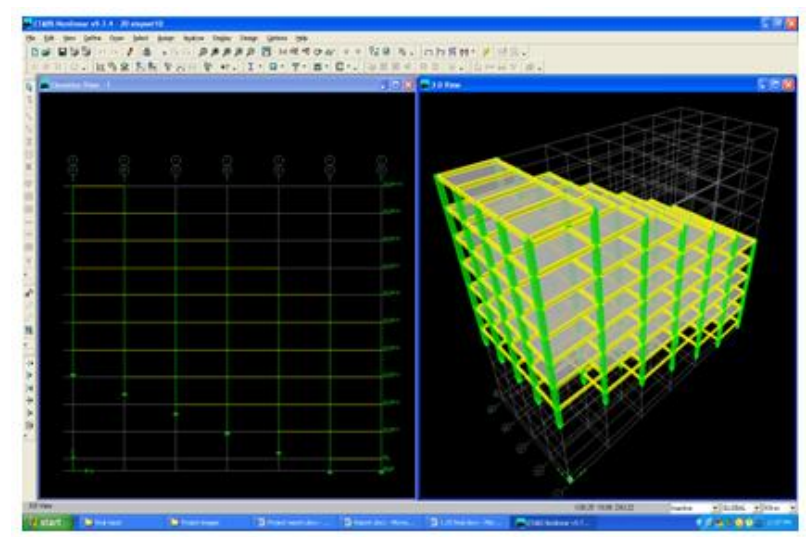

Fig 2.0: Typical 2D and 3D Step back set back building model on $20^{\circ}$ slope

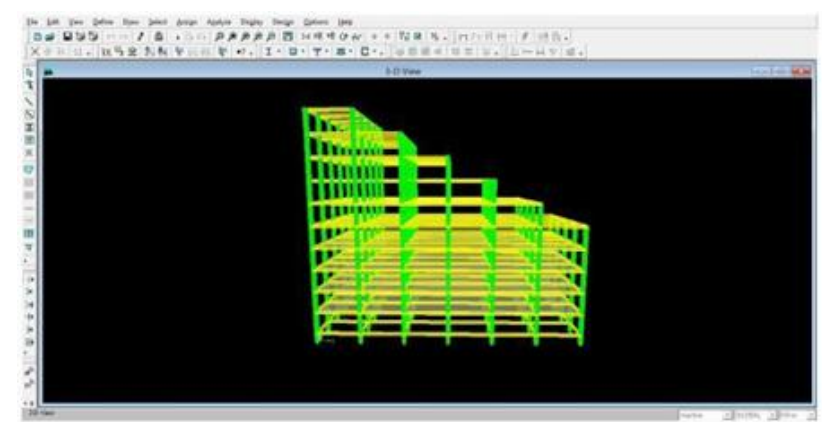

Fig 3.0: Typical 2D and 3D Set back building model on level ground

\section{Results And Discussion}

\section{Equivalent Static Method}

\section{(Top Storey Displacement, Base Shear and Storey Drift)}

Table-1: Analysis results of displacement, base shear, drift values obtained by Equivalent static method

\begin{tabular}{|c|c|c|c|c|c|c|c|c|}
\hline \multirow{2}{*}{$\begin{array}{l}\text { Model } \\
\text { configurat } \\
\text { ion }\end{array}$} & \multirow{2}{*}{$\begin{array}{l}\text { Slope } \\
\text { angle in } \\
\text { degree }\end{array}$} & \multicolumn{2}{|c|}{$\begin{array}{c}\text { Top storey } \\
\text { Displacement } \\
(\mathrm{mm})\end{array}$} & \multicolumn{2}{|c|}{ Top storey Drift (m) } & \multicolumn{2}{|c|}{ Base shear (kN) } & \multirow[t]{2}{*}{$\begin{array}{l}\text { Time } \\
\text { period }\end{array}$} \\
\hline & & EQX & EQY & EQX & EQY & EQX & EQY & \\
\hline \multirow{3}{*}{$\begin{array}{l}\text { STEP } \\
\text { BACK }\end{array}$} & 20 & 41.7 & 37.1 & 0.000464 & 0.00037 & 1241.17 & 1237.8 & 2.7599 \\
\hline & 30 & 29.4 & 27.5 & 0.000553 & 0.00037 & 1356.3 & 1125.05 & 2.2500 \\
\hline & 40 & 22.6 & 22.7 & 0.000778 & 0.000405 & 1968 & 1285.03 & 2.0650 \\
\hline \multirow{3}{*}{$\begin{array}{c}\text { STEP } \\
\text { BACK SET } \\
\text { BACK } \\
\end{array}$} & 20 & 41.4 & 42.6 & 0.000645 & 0.000425 & 1256.3 & 1255.08 & 2.0788 \\
\hline & 30 & 30 & 28.5 & 0.000781 & 0.000455 & 1379.53 & 1248.94 & 1.4687 \\
\hline & 40 & 24.4 & 17.3 & 0.001132 & 0.000517 & 1941.04 & 1507.48 & 1.2257 \\
\hline SET BACK & $\begin{array}{l}\text { LEVEL } \\
\text { GROUND }\end{array}$ & 69.603 & 57.81 & 0.000596 & 0.000471 & 1100.39 & 1100.39 & 2.756 \\
\hline
\end{tabular}

Displacement-

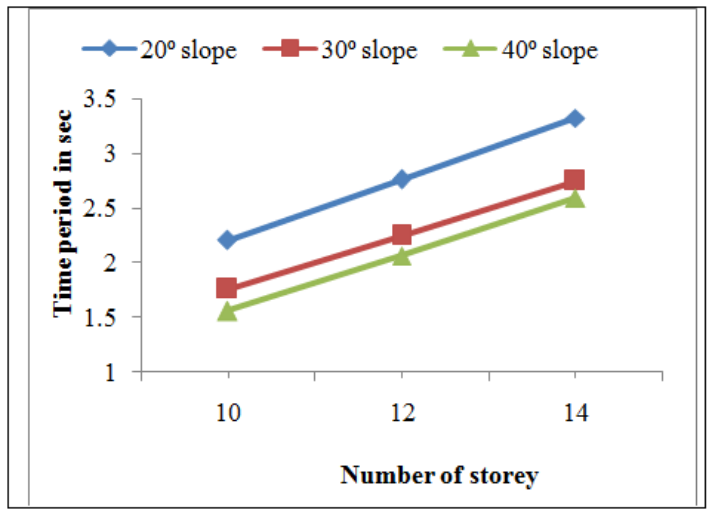

Fig 4.1: Variation of Time period For STP with respect to Slope angle 


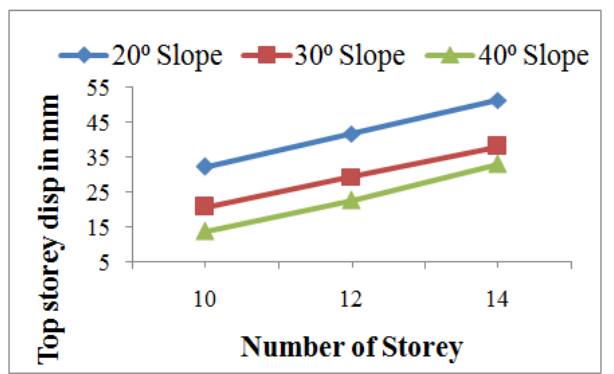

Fig 4.2: Variation of top storey displacement with respect to hill slope for STP buildings along longitudinal direction (Equivalent Static analysis)

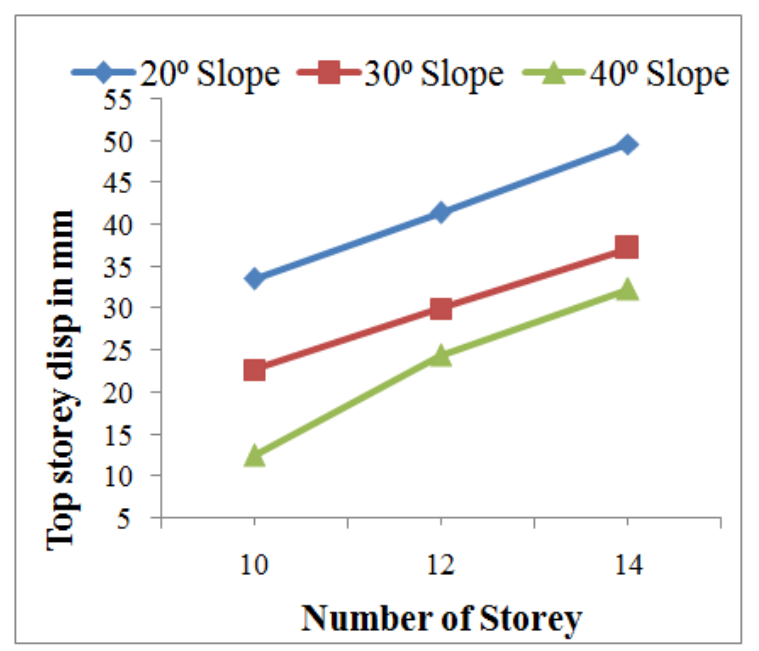

Fig 4.3: Variation of top storey displacement with respect to hill slope for STPSET buildings along longitudinal direction (Equivalent Static analysis).

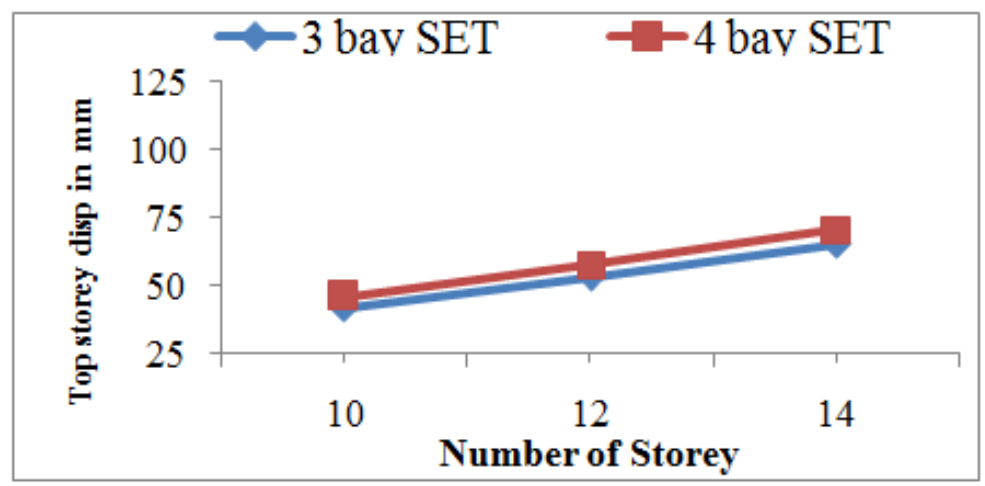

Drift-

Fig 4.4: Variation of top storey displacement on levelground

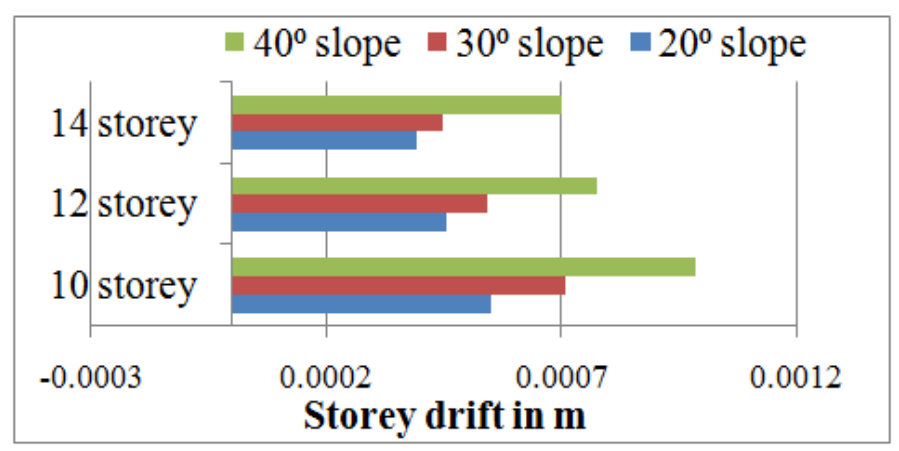

Fig 5.1: Variation of storey drift with respect to hill slope for STP building along longitudinal direction (Equivalent Static Analysis) 


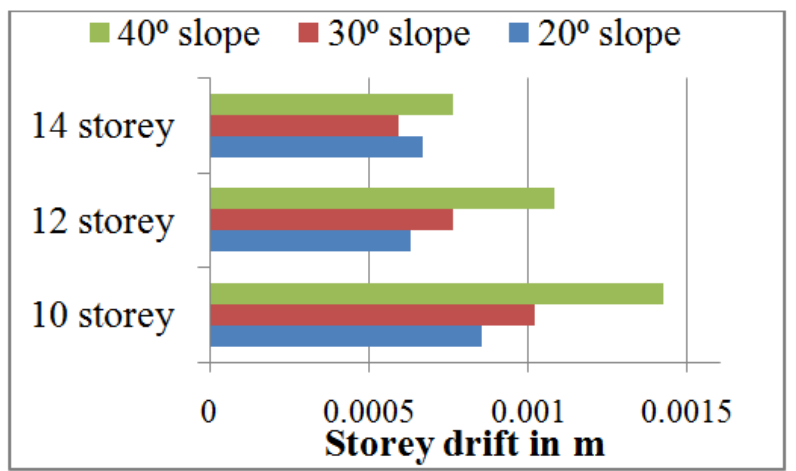

Fig 5.2: Variation of storey drift with respect to hill slope for STPSET building along longitudinal direction (Equivalent Static Analysis)

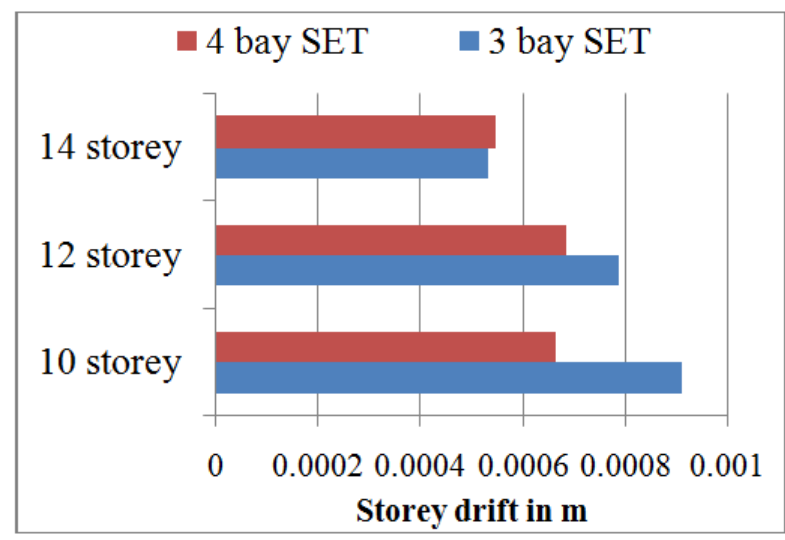

Fig 5.3: Variation of base shear with respect to number of bays across slope for SETback buildings along longitudinal direction (Equivalent Static analysis)

\section{$>$ Response Spectrum Method Step Back}

\section{Top Storey Displacement, Base Shear and Storey Drift}

Table -2: Analysis results of displacement, base shear, drift values obtained by Response spectrum method

\begin{tabular}{|c|c|c|c|c|c|c|c|c|}
\hline \multirow{2}{*}{$\begin{array}{l}\text { Model } \\
\text { configur } \\
\text { ation }\end{array}$} & \multirow{2}{*}{$\begin{array}{l}\text { Slope } \\
\text { angle in } \\
\text { degree }\end{array}$} & \multicolumn{2}{|c|}{$\begin{array}{ll}\text { Top } & \text { storey } \\
\text { Displacement }(\mathrm{mm})\end{array}$} & \multicolumn{2}{|c|}{ Top storey Drift (m) } & \multicolumn{2}{|c|}{ Base shear $(\mathrm{kN})$} & \multirow[t]{2}{*}{$\begin{array}{l}\text { Time } \\
\text { period }\end{array}$} \\
\hline & & EQX & EQY & EQX & EQY & EQX & EQY & \\
\hline \multirow{3}{*}{$\begin{array}{l}\text { STEP } \\
\text { BACK }\end{array}$} & 20 & 39.1 & 33.7 & 0.0006 & .000626 & 1399.47 & 1345.07 & 2.7599 \\
\hline & 30 & 24.8 & 24.3 & 0.000671 & .000595 & 1775.21 & 1167.21 & 2.2500 \\
\hline & 40 & 18.6 & 20.4 & 0.000778 & .000618 & 2303.89 & 1340.85 & 2.0650 \\
\hline \multirow{3}{*}{$\begin{array}{l}\text { STEP } \\
\text { BACK } \\
\text { SET } \\
\text { BACK }\end{array}$} & 20 & 36.7 & 39.3 & 0.000927 & .000457 & 1302.56 & 1363.11 & 2.0788 \\
\hline & 30 & 23.7 & 23.4 & 0.001055 & .000507 & 1653.97 & 1302.75 & 1.4687 \\
\hline & 40 & 18.1 & 10.1 & 0.001132 & .000355 & 2075.01 & 1517.91 & 1.2257 \\
\hline $\begin{array}{l}\text { SET } \\
\text { BACK }\end{array}$ & $\begin{array}{l}\text { Level } \\
\text { Ground }\end{array}$ & 44.496 & 51.694 & 0.000492 & 0.000413 & 961.65 & 936.68 & 2.756 \\
\hline
\end{tabular}

\section{Displacement-}

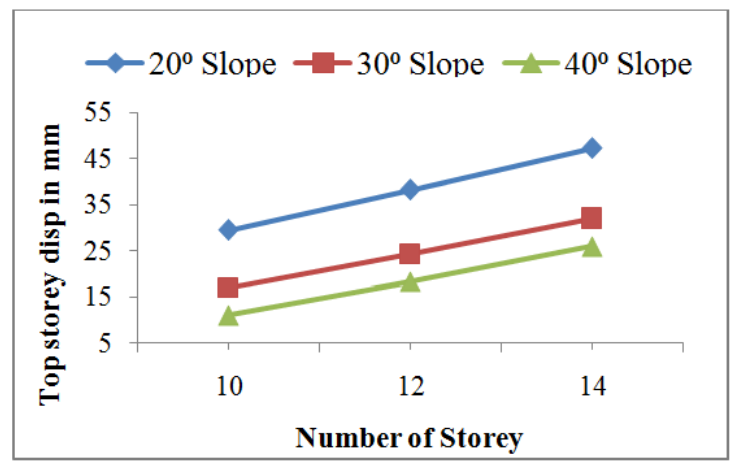

Fig 5.1: Variation of top storey displacement with respect to hill slope for STP buildings along longitudinal direction (Response Spectrum Analysis) 


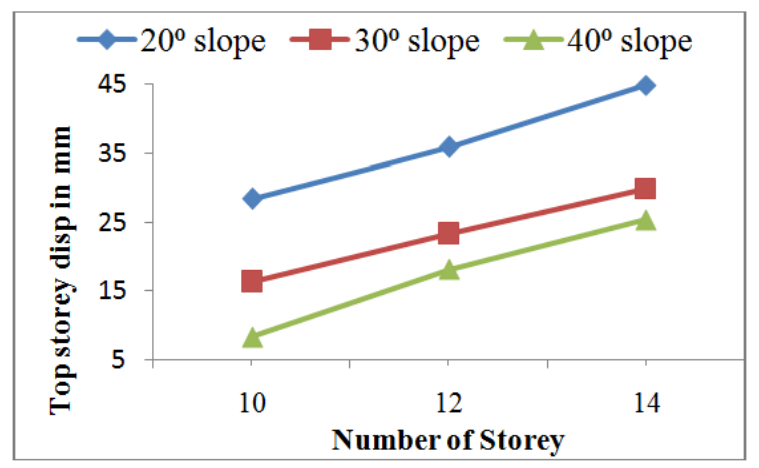

Fig 5.2: Variation of top storey displacement with respect to hill slope for STPSET buildings along longitudinal direction (Response Spectrum Analysis).

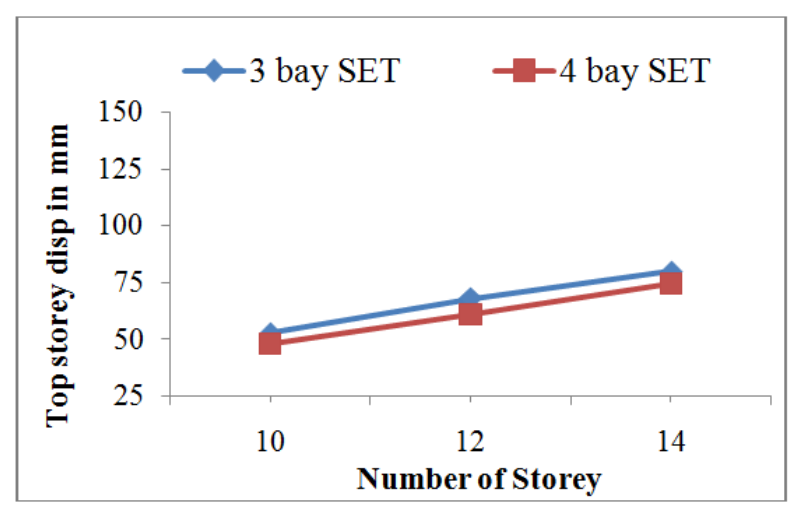

Fig 5.3: Variation of top storey displacement on levelground

\section{Base Shear -}

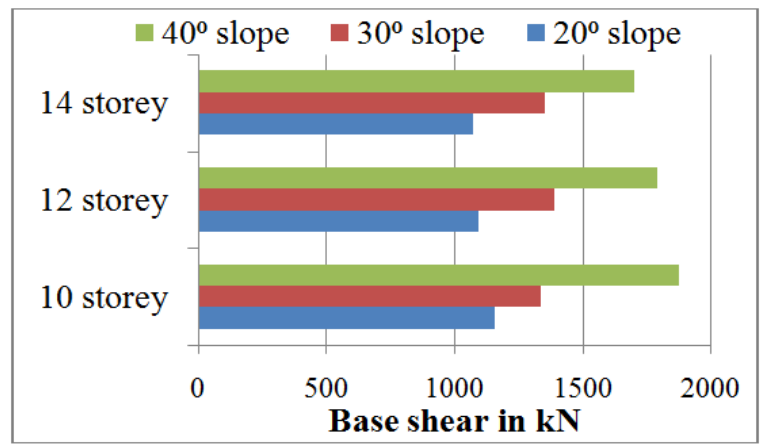

Fig 5.4: Variation of base shear with respect to hill slope for STP buildings along longitudinal direction (Response Spectrum analysis)

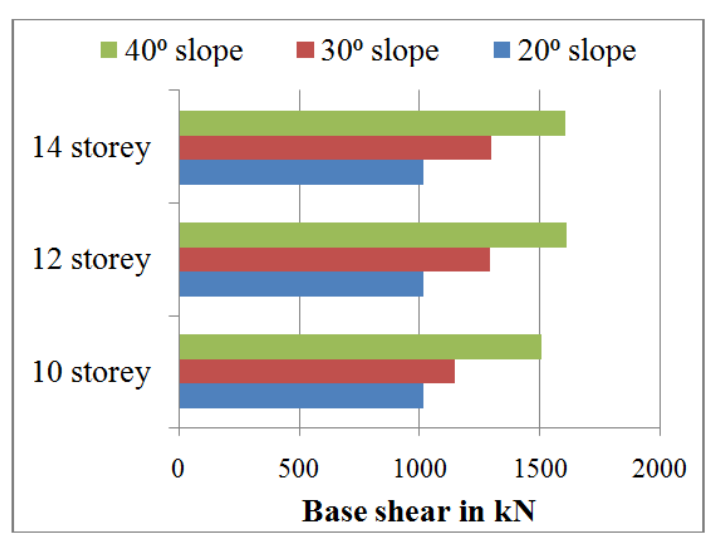

Fig 5.5: Variation of base shear with respect to hill slope for STPSET buildings along longitudinal direction (Response Spectrum analysis) 
Drift -

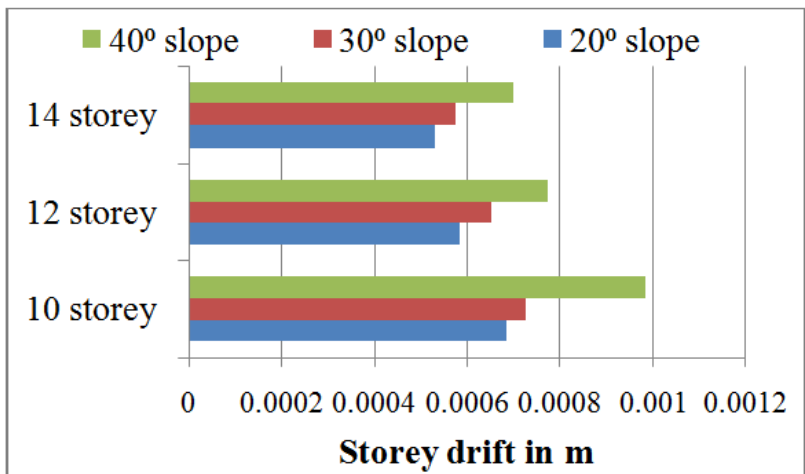

Fig 5.6: Variation of storey drift with respect to hill slope for STP building along longitudinal direction (Response Spectrum Analysis)

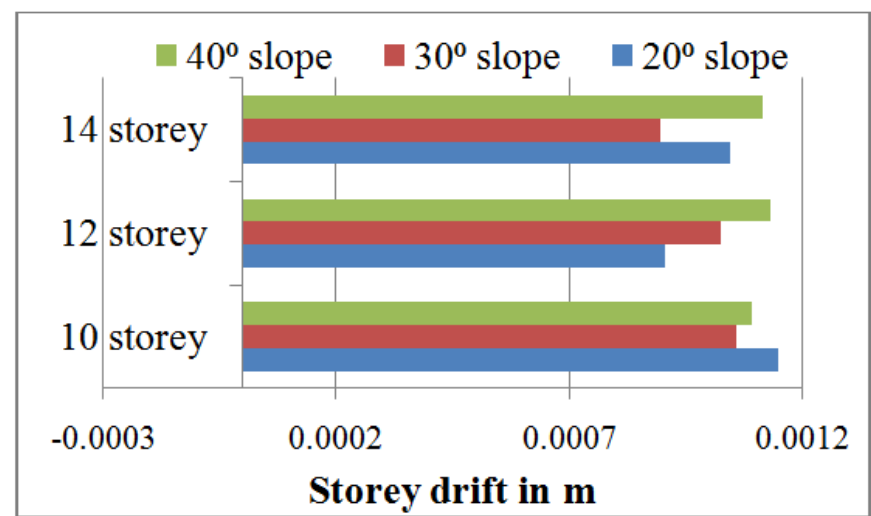

Fig 5.7: Variation of storey drift with respect to hill slope for STPSET building along longitudinal direction (Response Spectrum Analysis)

\section{Conclusions}

Based on the study carried out and the results obtained, the following conclusions can be drawn.

1. Time period and top storey displacement increases with increase in number of story level. Base shear, storey drift decreases with increase in number of story level.

2. Step back buildings produces higher value of time period, top storey displacement and base shear than Step back Set back building frames.

3. Step back set back buildings produces $45-60 \%$ higher value of storey drift than Step back buildings.

4. As the number of bays increases across slope direction, time period decreases, however, top storey displacement, base shear, storey drift increases due higher stiffness.

5. As the Slope angle increases, time period, top storey displacement decreases, which indicates that the stiffness is increasing of the buildings with increase in hill slope.

6. As the Slope angle increases, Base shear, Storey drifts increases.

7. In case of buildings resting on sloping ground, short column on uphill side attracts maximum shear force in the range of $39-319 \%$, compared to adjacent long columns, which are the worst affected due to seismic excitation. Special attention should be given while designing these columns.

8. Step back set back buildings may be favoured on sloping ground, provided special attention is given to reduce storey drift.

9. Buildings resting on higher angle are the critical buildings, as they produce $58-63 \%$ higher value of base shear and $31-43 \%$ higher value of storey drift than the buildings resting on lower slope angles.

\section{References}

[1]. Birajdar.B.G,"Seismic analysis of buildings resting on sloping ground", 13thWorld Conference on Earthquake Engineering, Vancouver, B.C., Canada, Paper No. 1472, 2004.

[2]. S.M.Nagargoje and K.S.Sable," Seismic performance of multi-storeyed building on sloping ground", Elixir International Journal, 7 December 2012. 11980-11982.

[3]. Y. Singh and Phani Gade "Seismic Behavior of Buildings Located on Slopes" - An Analytical Study and Some Observations From Sikkim Earthquake of September 18, 2011. 15th World Conference on Earthquake Engineering Journal 2012.

[4]. Mohammed Umar Farooque Patel et al "A Performance study and seismic evaluation of RC frame buildings on sloping ground" IOSR Journal of Mechanical and Civil Engineering (IOSR-JMCE) e-ISSN: 2278-1684, p-ISSN: 2320-334X-,2014, pp 51-58 
[5]. Prashant D, Dr. Jagadish Kori G “ Seismic Response of one way slope RC frame building with soft storey" International Journal of Emerging Trends in Engineering and Development Issue 3, Vol.5 (September 2013), pp 311-320

[6]. Rayyan-Ul-Hasan Siddiqui and, H. S. Vidyadhara "Seismic Analysis of Earthquake Resistant Multi Bay Multi Storeyed 3D - RC Frame” International Journal of Engineering Research \& Technology (IJERT) ISSN: 2278-0181 Vol. 2 Issue 10, October - 2013, pp 489-495.

[7]. N. Jitendra Babu, K.Y.G.D Balaji "pushover analysis of unsymmetrical framed structures on sloping ground” International Journal of Civil, Structural, Environmental and Infrastructure Engineering Research and Development (IJCSEIERD) ISSN 2249-6866 Vol. 2 Issue 4 Dec - 2012, pp 45-53.

[8]. Ravikumar C M,*, Babu Narayan K S "Effect of Irregular Configurations on Seismic Vulnerability of RC Buildings" Architecture Research 2012,2(3):20-26DOI: 10.5923/j.arch.20120203.01, pp 20-26

[9]. Dr. S. A. Halkude et al "Seismic Analysis of Buildings Resting on Sloping Ground With Varying Number of Bays and Hill Slopes" International Journal of Engineering Research and Technology ISSN:2278-0181,Vol.2 Issue 12, December-2013, pp 3632-3640

[10]. Prabhat Kumar et al "Influence of soil-structure interaction in seismic response of step-back buildings" Indian Society of Earthquake Technology, Department of Earthquake Engineering Building IIT Roorkee, Roorkee, Paper No. C013, October 20-21, 2012.

[11]. IS: 1893 (I)-2002. "Criteria for Earthquake Resistant Design of Structures” BIS, New Delhi.

[12]. Structural Analysis program ETABS V 9.7.4, "User's manual, computers and structures, Inc.

[13]. S.K.Duggal "Earthquake resistant design of structures" Oxford university press 2007, ISBN-13:978-0-19-568817-7. 